Reprod. Nutr. Dévelop., 1987, 27 (5), 941-944.

\title{
The development of sheep embryos when two are transferred into only one uterine horn or into each uterine horn
}

\author{
Suzanne TORRĖS, Claude SEVELLEC
}

Station de Physiologie animale, I.N.R.A. 78350 Jouy-en-Josas, France.

Summary. In two series of experiments, two D6 morulae were surgically transferred either to each uterine horn of recipient ewes or to the same horn.

When embryos were transferred to each side, the percentages of lambs born were not significantly different (68 and $62.5 \%$ respectively) whether the corpora lutea of recipient ewes were on each ovary or on the same ovary (in this case, embryos were transferred to the horn ipsilateral to the corpora lutea).

When embryos were transferred to the same horn, the percentages of lambs born (71 and $92.6 \%$ respectively) were not significantly different whether the corpora lutea were on each side or on the same side.

The percentages of lambs born were not significantly different whether the two morulae were transferred to each uterine horn or to the same horn.

\section{Introduction.}

In domestic mammals, the efficiency of selection must be considerably increased by superovulation followed by embryo transfer in unselected recipients.

White et al. (1981) have shown that in normal reproduction twinning rates are higher after bilateral ovulation when both ovulations occur on the same ovary. According to these authors, the transuterine migration of an embryo from the opposite side, which occurs at the beginning of gestation in unilateral double ovulation, results in embryonic loss.

Using a surgical method, we have compared results obtained after placing two embryos in the same horn to those obtained with bilateral transfer.

\section{Material and methods.}

The donor ewes were given a superovulation treatment, using the technique already published (Torrès et al., 1987). The embryos recovered were at the compact morula or young blastocyst stage (D6 of pregnancy).

The recipient ewes were synchronized with the donors and operated at D6 (DO = first day of oestrus). Using a catheter connected with a syringe and with a 
needle at one end, we injected the embryo(s) using one per horn, even if there was only one ovulation.

We always transferred the embryo(s) to the side ipsilateral to the corpus luteum, which could leave one uterine horn empty, depending on the distribution of the ovulations.

In the first series of experiments, 94 recipients received one morula in each uterine horn. In the second series of experiments, two embryos were transferred into the same horn on the side ipsilateral to the corpus luteum. Twenty-five recipient ewes were used.

Nulliparous "Préalpes » ewes were used as donors and recipients. Ewes which were expected to be pregnant at Day 18 by progesterone dosage were allowed to lamb.

\section{Results.}

The transfer of one embryo into each uterine horn (table 1) gave the same proportion of pregnant ewes, whether the corpora lutea were on the same ovary or distributed on the two ovaries. The proportions of lambs born compared to the number of morulae transferred were 69 and $62.5 \%$, respectively ; the difference was not significant.

TABLE 1

Transfer of one embryo into to each uterine horn

\begin{tabular}{cccccc}
\hline & $\begin{array}{c}\text { No. of } \\
\text { recipients }\end{array}$ & $\begin{array}{c}\text { No. of corpora } \\
\text { lutea }\end{array}$ & $\begin{array}{c}\text { No. of } \\
\text { pregnancies }\end{array}$ & $\begin{array}{c}\text { No. of empty } \\
\text { ewes }\end{array}$ & $\begin{array}{c}\text { No. of lambs } \\
\text { born }\end{array}$ \\
\hline $\begin{array}{c}1 \mathrm{CL} \text { on } \\
\text { each side }\end{array}$ & 50 & 112 & $41(82 \%)$ & $9(18 \%)$ & $\begin{array}{c}68 / 100(1) \\
(68 \%)\end{array}$ \\
\hline $\begin{array}{c}1 \text { or } 2 \\
\mathrm{CL} \text { on } \\
\text { same side }\end{array}$ & 44 & 80 & $34(77 \%)$ & $10(23 \%)$ & $\begin{array}{c}55 / 88(1) \\
(62.5 \%)\end{array}$ \\
\hline
\end{tabular}

(1) number of embryos transferred.

When two embryos were transferred into the same horn (table 2), in the presence of bilateral or unilateral corpora lutea, the proportions of pregnant ewes were 82 and $93 \%$, respectively. The differences were not significant and neither was the percentage of lambs born in relation to the number of embryos transferred $(71.4$ and $92.6 \%)$.

When the percentages of gestation and of embryonic survival were compared as to type of transfer (tables 1,2 ) the differences were not significant. Only one recipient that was diagnosed as positive at D18 had not lambed. No lambs were born dead. 
TABLE 2

Transfer of two embryos into the same uterine horn

\begin{tabular}{cccccc}
\hline & $\begin{array}{c}\text { No. of } \\
\text { recipients }\end{array}$ & $\begin{array}{c}\text { No. of corpora } \\
\text { lutea }\end{array}$ & $\begin{array}{c}\text { No. of } \\
\text { pregnancies }\end{array}$ & $\begin{array}{c}\text { No. of empty } \\
\text { ewes }\end{array}$ & $\begin{array}{c}\text { No. of lambs } \\
\text { born }\end{array}$ \\
\hline $\begin{array}{c}1 \text { CL on } \\
\text { each side }\end{array}$ & 11 & 29 & $9(82 \%)$ & $2(18 \%)$ & $\begin{array}{c}15 / 21(1)(2) \\
(71.4 \%)\end{array}$ \\
\hline $\begin{array}{c}1 \text { or } 2 \\
\text { CL on } \\
\text { same side }\end{array}$ & 14 & 27 & $13(93 \%)$ & $1(7 \%)$ & $\begin{array}{c}25 / 27(1)(2) \\
(92.6 \%)\end{array}$ \\
\hline
\end{tabular}

(1) number of embryos transferred.

(2) one recipient received only one embryo.

\section{Discussion.}

In cows, the transfer of two embryos, one on each side, in the presence of only one corpus luteum, causes embryonic loss on the side contralateral to the corpus luteum : survival at D115 of gestation is only $30.8 \mathrm{vs} 69.2 \%$ in the ipsilateral horn (Sreenan et al., 1975). When Tervit et al. (1977) transferred the embryo to the side either ipsilateral or contralateral to the corpus luteum, they obtained 54 and $39 \%$ of gestation, respectively, on D41. Although survival was less good in the contralateral horn, the difference was not significant. However, these results resemble those of Sreenan, and the fact that the percentages found by Tervit were not significant could be due to earlier diagnosis of pregnancy at a stage (between D41 and D115) when there is a tendency for embryonic loss.

In cows, there seems to be a local relationship between the corpus luteum, the embryo and its position in the uterus.

In agreement with Kelly and Johnstone (1983), our results show that the presence of two embryos in the same uterine horn does not impair future development, and the migration of an embryo into the empty horn - which occurs during accelerated growth when the embryo becomes a long, filiform vesicle (D13-14) - does not affect survival. This observation does not agree with the hypothesis of White et al. (1981) who suppose that this migration is the main reason for the failure of twin pregnancies when double ovulations occur on the same ovary.

Transfer using laparoscopy may thus be simplified since two morulae can be injected into the same uterine horn.

Acknowledgements. - We wish to thank Mrs Daifuku for the English translation. 
Résumé. Développement des embryons ovins après transfert dans une seule ou dans chacune des cornes utérines.

On a comparé le développement de morulae de j6 après transfert chirurgical soit d'un embryon dans chaque corne utérine de brebis receveuses ou de deux embryons dans la même corne utérine [transfert du côté ipsilatéral au( $x)$ corps jaune(s)].

La position du ou des corps jaunes sur les ovaires, n'a pas d'influence sur le taux de gestation et le nombre d'agneaux nés quand un embryon est transplanté de chaque côté $168 \%$ avec 1 corps jaune de chaque côté et $62,5 \%$ avec 1 ou 2 corps jaunes sur le même ovaire).

Le transfert de 2 embryons dans une seule corne utérine lipsilatérale au(x) corps jaune(s)] donne $71,4 \%$ d'agneaux quand chaque ovaire porte un corps jaune et $92,6 \%$ lorsque les deux ovulations sont situées sur l'ovaire correspondant à la corne utérine recevant les embryons.

Les pourcentages de réussite ne sont pas significativement différents entre les transferts bilatéraux et unilatéraux. Ces résultats permettent d'envisager la simplification des transferts par laparoscopie.

\section{Références}

KELLY R. W., JOHNSTONE P. D., 1983. The influence of site of ovulation on the reproductive performance of ewes with I or two ovulations. New $Z$. J. agric. Res., 26, $433-435$.

SREENAN J. M., BEEHAN D., MULVEHILL P., 1975. Egg transfer in the cow: factors affecting pregnancy and twinning rate following bilateral transfers. J. Reprod. Fert., 44, 77 85.

TERVIT H. R., HAVIK P. G., SMITH J. F., 1977. Egg transfer in cattle : pregnancy rate following transfer to the uterine horn ipsilateral or contralateral to the functional corpus luteum. Theriogenology, 7, 3-10.

TORRESS S., COGNIE Y., COLAS G., 1987. Transfer of superovulated sheep embryos obtained with different FSH-P. Theriogenology, 27, 407-419.

WHITE D. H., RIZZOLI D. J., CUMMING I. A., 1981. Embryo survival in relation to number and site of ovulations in the ewe. Aust. J. exp. Agric. anim. Husb., 21, 32-38. 